Article

\title{
Exploring Prokaryotic and Eukaryotic Microbiomes Helps in Detecting Tick-Borne Infectious Agents in the Blood of Camels
}

\author{
Wessam Mohamed Ahmed Mohamed ${ }^{1}{ }^{\circledR}$, Alsagher O. Ali ${ }^{2}$, Hassan Y. A. H. Mahmoud ${ }^{2}{ }^{\oplus}$, Mosaab A. Omar ${ }^{3,4}{ }^{\circledR}$, \\ Elisha Chatanga ${ }^{1,5} \mathbb{D}^{\circ}$, Bashir Salim ${ }^{6}{ }^{\mathbb{C}}$, Doaa Naguib ${ }^{1,7}$, Jason L. Anders ${ }^{8}$, Nariaki Nonaka ${ }^{1}$, \\ Mohamed Abdallah Mohamed Moustafa $1,9, *$ (i) and Ryo Nakao ${ }^{1, *(1)}$
}

1 Laboratory of Parasitology, Faculty of Veterinary Medicine, Graduate School of Infectious Diseases, Hokkaido University, Sapporo, Hokkaido 060-0818, Japan; wessam@czc.hokudai.ac.jp (W.M.A.M.); chatanga@vetmed.hokudai.ac.jp (E.C.); abassdoaa@yahoo.com (D.N.); nnonaka@vetmed.hokudai.ac.jp (N.N.)

2 Division of Infectious Diseases, Animal Medicine Department, Faculty of Veterinary Medicine, South Valley University, Qena 83523, Egypt; alsagher.ali@vet.svu.edu.eg (A.O.A.); mhassan@vet.svu.edu.eg (H.Y.A.H.M.)

3 Department of Parasitology, Faculty of Veterinary Medicine, South Valley University, Qena 83523, Egypt; dr_mosab2081@yahoo.com

4 Department of Veterinary Medicine, College of Agriculture and Veterinary Medicine, Qassim University, Buraidah 51452, Saudi Arabia

5 Department of Veterinary Medicine, Lilongwe University of Agriculture and Natural Resources, Lilongwe P.O. BOX 219, Malawi

check for updates

Citation: Mohamed, W.M.A.; Ali, A.O.; Mahmoud, H.Y.A.H.; Omar, M.A.; Chatanga, E.; Salim, B.; Naguib, D.; Anders, J.L.; Nonaka, N.; Moustafa, M.A.M.; et al. Exploring Prokaryotic and Eukaryotic Microbiomes Helps in Detecting Tick-Borne Infectious Agents in the Blood of Camels. Pathogens 2021, 10, 351. https://doi.org/10.3390/ pathogens 10030351

Academic Editor:

Alejandro Cabezas-Cruz

Received: 22 January 2021

Accepted: 9 March 2021

Published: 16 March 2021

Publisher's Note: MDPI stays neutral with regard to jurisdictional claims in published maps and institutional affiliations.

Copyright: (c) 2021 by the authors. Licensee MDPI, Basel, Switzerland. This article is an open access article distributed under the terms and conditions of the Creative Commons Attribution (CC BY) license (https:/ / creativecommons.org/licenses/by/ $4.0 /)$.
6 Department of Parasitology, Faculty of Veterinary Medicine, University of Khartoum, Khartoum North 11111, Sudan; bashirsalim@gmail.com

7 Department of Hygiene and Zoonoses, Mansoura University, Mansoura 35516, Egypt

8 Graduate School of Environmental Science, Hokkaido University, Sapporo, Hokkaido 060-0810, Japan; janderslee@ees.hokudai.ac.jp

9 Division of Wildlife Medicine, Animal Medicine Department, Faculty of Veterinary Medicine, South Valley University, Qena 83523, Egypt

* Correspondence: m.abdallah@vetmed.hokudai.ac.jp (M.A.M.M.); ryo.nakao@vetmed.hokudai.ac.jp (R.N.); Tel./Fax: +81-11-706-5196 (M.A.M.M.); Tel./Fax: +81-11-706-5196 (R.N.)

Abstract: Dromedary camels (Camelus dromedarius) are widely distributed in Africa, the Middle East and northern India. In this study, we aimed to detect tick-borne pathogens through investigating prokaryotic and eukaryotic microorganisms in camel blood based on a metagenomic approach and then to characterize potentially pathogenic organisms using traditional molecular techniques. We showed that the bacteria circulating in the blood of camels is dominated by Proteobacteria, Bacteroidetes, Firmicutes and Actinobacteria. At the genus level, Sediminibacterium, Hydrotalea, Bradyrhizobium and Anaplasma were the most abundant taxa. Eukaryotic profile was dominated by Fungi, Charophyta and Apicomplexa. At the genus level, Theileria was detected in 10 out of 18 samples, while Sarcocystis, Hoplorhynchus and Stylocephalus were detected in one sample each. Our metagenomic approach was successful in the detection of several pathogens or potential pathogens including Anaplasma sp., Theileria ovis, Th. separata, Th. annulate, Th. mutans-like and uncharacterized Theileria sp. For further characterization, we provided the partial sequences of citrate synthase ( $g l t A)$ and heat-shock protein (groEL) genes of Candidatus Anaplasma camelii. We also detected Trypanosoma evansi type A using polymerase chain reaction (PCR) targeting the internal transcribed spacer 1 (ITS1) region. This combined metagenomic and traditional approach will contribute to a better understanding of the epidemiology of pathogens including tick-borne bacteria and protozoa in animals.

Keywords: Candidatus Anaplasma camelii; eukaryotes; microbiome; Theileria; Trypanosoma evansi

\section{Introduction}

Camels are divided into three species, the Arabian or dromedary camel (Camelus dromedarius), the Bactrian camel (Camelus bactrianus) and the wild Bactrian camel (Camelus ferus) [1,2]. 
Arabian camels are commonly used for meat and milk production, transportation and racing [3]. There are many species of ticks that can infest camels including Hyalomma anatolicum, Hy. excavatum, Hy. scupense, Hy. dromedarii, Hy. impeltatum, Hy. marginatum, Hy. rufipes, Hy. truncatum, Ornithodoros savignyi, Rhipicephalus praetextatus and Rh. turanicus [4]. Such ticks can act as vectors for pathogens harbored by camels such as Rickettsia, Anaplasma, Ehrlichia, Coxiella, Babesia, Hepatozoon and Theileria [3,5-9], which represent a potential risk to other animals and humans. Despite the importance of camels in the livelihood of people, scarce information is available on their role in maintaining tick-borne pathogens (TBPs) as compared to other animals [10].

The metagenomic approach utilizing high-throughput sequencing techniques has contributed largely to the description of pathogenic and nonpathogenic microbes in many animal species. It is not limited to the simultaneous detection of known pathogens but also detection of novel potential pathogens [11]. The most common genetic markers targeted for metagenomic investigations are 16S rDNA and 18S rDNA for prokaryotes and eukaryotes, respectively [12]. However, polymerase chain reaction (PCR) using universal primers primarily amplifies the $18 \mathrm{~S}$ rDNA of host animals rather than those of animal-associated eukaryotes, thereby limiting the use of metagenomics for such studies [13]. A PCR using non-metazoan universal primers (UNonMet-PCR), which was originally developed for the selective amplification of oyster protists [14], has been used to reduce the amplicons from metazoan $18 S$ rDNA with high ability to amplify the V4 region of $18 \mathrm{~S}$ rDNA from other eukaryotes within animal hosts [11]. Although this PCR can theoretically be used for many types of samples, it has not yet been applied for the detection of eukaryotes within the mammalian blood.

The study of blood parasites in mammals by conventional PCR or quantitative PCR can only detect genetically identified species [15]. However, next-generation sequencing (NGS)-based techniques can provide a thorough characterization of the eukaryome $[16,17]$. Furthermore, although it is thought that healthy mammalian blood should be sterile [18], some studies have provided evidence that there is a blood associated microbiome [19-21].

The present study aims to describe both the prokaryotic and eukaryotic profiles in the blood of dromedary camels in Egypt. The results were further verified by conventional genetic assays amplifying genus or species-specific genes. Our data indicate the usefulness of metagenomic approach for the detection of pathogens, but at the same time, suggest the necessity to refine current methods to capture a full picture of the blood microbiome in camels.

\section{Results}

\subsection{Bacterial Profile}

The NGS targeting 16S rDNA resulted in a total number of 920,376 raw paired-end reads. DADA2 quality control analysis resulted in 403,680 high-quality paired-end reads with an average of 21,246 per sample with a maximum of 41,514 and minimum of 9,723. Sequences were divided into 3,772 amplicon sequence variants (ASVs). The possible contaminants in the negative control composed of two main phyla, the Proteobacteria and Firmicutes, which contain nine genera: Pseudomonas, Escherichia-Shigella, Bacillus, Serratia, Novosphingobium, Curvibacter, Halomonas, Candidatus Lariskella and Coxiella (Table S1). After removing these contaminants from each sample, we finally obtained 333,054 reads divided into 2372 features. The mean frequency per sample was 18,503 and the median average was 16,856 reads. The most abundant phyla were Proteobacteria (mean $=46.7 \%$ ), Bacteroidetes $($ mean $=24.1 \%)$, Firmicutes $($ mean $=16.9 \%)$ and Actinobacteria $($ mean $=8.2 \%)$. At the genus level, Sediminibacterium (mean $=13.8 \%)$, Hydrotalea $($ mean $=8.6 \%)$, Bradyrhizobium $($ mean $=7.9 \%)$, Anaplasma $($ mean $=6.4 \%)$ and Ralstonia $($ mean $=3.4 \%)$ were the highest abundant (Figure 1 and Table S2). The genera Sediminibacterium, Hydrotalea and Bradyrhizobium were detected in all samples, while Anaplasma was detected in 11 samples (Table 1). Other known tick-borne bacteria including Borrelia, Rickettsia and Ehrlichia were not detected in our samples. 


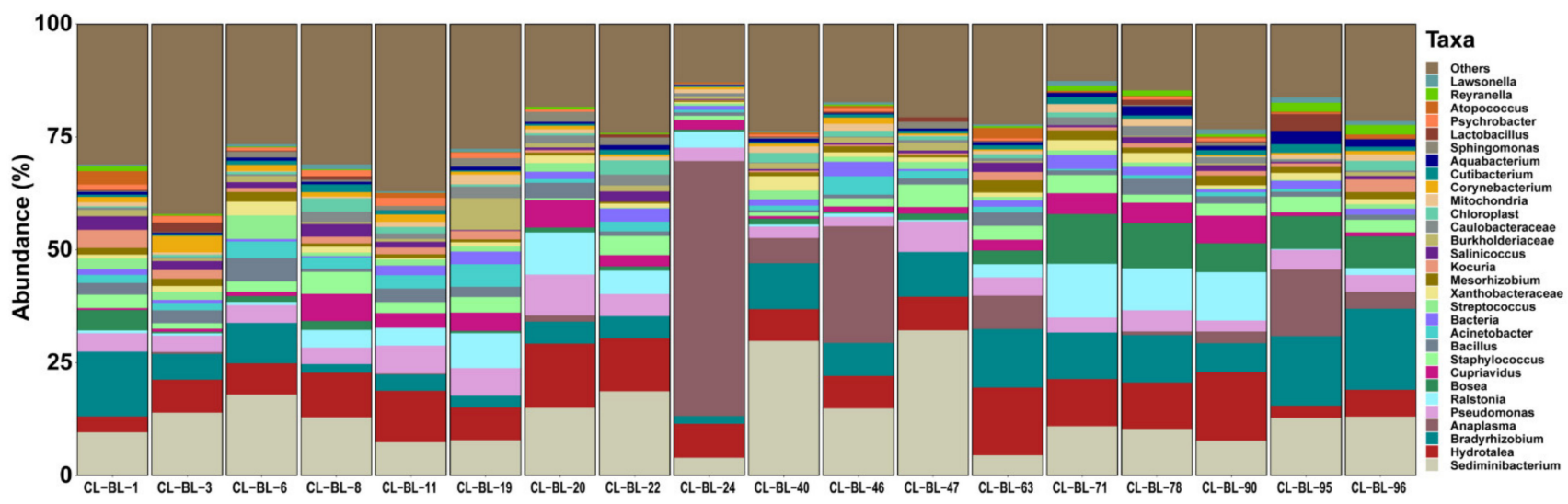

Figure 1. Relative abundance of bacterial genera detected in 18 camel blood samples. Each bar represents the bacterial taxa detected in one camel sample. The sample ID is provided on the bottom of each bar.

Table 1. A summary of the number of reads originating from the tick-borne pathogens detected in this study.

\begin{tabular}{|c|c|c|c|c|c|c|}
\hline Sample ID & $\begin{array}{c}\text { Candidatus } \\
\text { Anaplasma } \\
\text { Camelii }\end{array}$ & $\begin{array}{l}\text { Theileria } \\
\text { annulata }\end{array}$ & Theileria ovis & $\begin{array}{l}\text { Theileria } \\
\text { separata }\end{array}$ & $\begin{array}{c}\text { Theileria } \\
\text { mutans-Like * }\end{array}$ & Theileria sp. \\
\hline CL-BL-1 & 28 & 0 & 488 (LC592658) & 0 & 241 (LC592666) & 65 (LC592660) \\
\hline CL-BL-3 & 0 & 0 & 171 (LC592657) & 0 & 0 & 0 \\
\hline CL-BL-6 & 0 & 0 & 0 & 0 & 0 & 0 \\
\hline CL-BL-8 & 324 & 0 & 175 (LC592656) & 0 & 0 & 0 \\
\hline CL-BL-11 & 0 & 0 & 120 (LC592659) & 0 & 0 & 0 \\
\hline CL-BL-19 & 13,101 & 314 (LC592651) & 434 (LC592655) & 0 & 0 & 0 \\
\hline CL-BL-20 & 128 & 0 & $\begin{array}{c}1252 \\
(\mathrm{LC} 592654)\end{array}$ & 0 & 572 (LC592665) & 0 \\
\hline CL-BL-22 & 931 & 0 & 0 & 0 & 0 & 0 \\
\hline CL-BL-24 & 1914 & 0 & $\begin{array}{c}2945 \\
\text { (LC592653) }\end{array}$ & 626 (LC592662) & $\begin{array}{c}1360 \\
\text { (LC592664) }\end{array}$ & 0 \\
\hline CL-BL-40 & 0 & 0 & 0 & 0 & 0 & 0 \\
\hline CL-BL-46 & 909 & 0 & 0 & 0 & 0 & 0 \\
\hline CL-BL-47 & 0 & 0 & 0 & 558 (LC592661) & 0 & 0 \\
\hline CL-BL-63 & 0 & 0 & 0 & 0 & 77 (LC592663) & 0 \\
\hline CL-BL-71 & 88 & 0 & 513 (LC592652) & 0 & 0 & 0 \\
\hline CL-BL-78 & 0 & 0 & 0 & 0 & 0 & 0 \\
\hline CL-BL-90 & 461 & 0 & 0 & 0 & 0 & 0 \\
\hline CL-BL-95 & 2738 & 0 & 0 & 0 & 0 & 0 \\
\hline CL-BL-96 & 589 & 0 & 0 & 0 & 0 & 0 \\
\hline
\end{tabular}

* Theileria mutans-like was identified as Theileria sp. strain MSD by silva-132-99-nb classifier in QIIME2. ** GenBank accession numbers are shown in brackets.

\subsection{Eukaryotic Profile}

A total number of $1,643,804$ raw paired-end reads of $18 \mathrm{~S}$ rDNA were obtained. A total of 728,071 high-quality paired-end reads remained after quality filtering using the DADA2 quality control analysis and classified into 353 unique features with a mean frequency per sample of 38,319 with a maximum of 52,151 and minimum of 10,668. The possible contaminants in the negative control composed mainly of fungi and Ochrophyta (Table S3). 
In addition, the sequences of the most abundant taxon Metazoa (mean $=72.9 \%$ ), which were derived from host DNA, were considered as contaminants. By filtering out the contaminants from each sample, a total of 189,914 reads divided into 275 features were obtained. The mean frequency per sample was 10,550 and the median average was 8933 reads. The most abundant taxa were Fungi $($ mean $=52.1 \%)$, Charophyta $($ mean $=38.8 \%)$, Apicomplexa $($ mean $=5.5 \%)$ and Cercozoa $($ mean $=1.3 \%)$. The phylum Apicomplexa was dominated by the genus Theileria, which was detected in 10 samples (Table 1). The genera Sarcocystis, Hoplorhynchus and Stylocephalus were detected in one sample each (Figure 2 and Table S4). Other known tick-borne bacterial genera including Babesia and Hepatozoon were not detected in our samples.

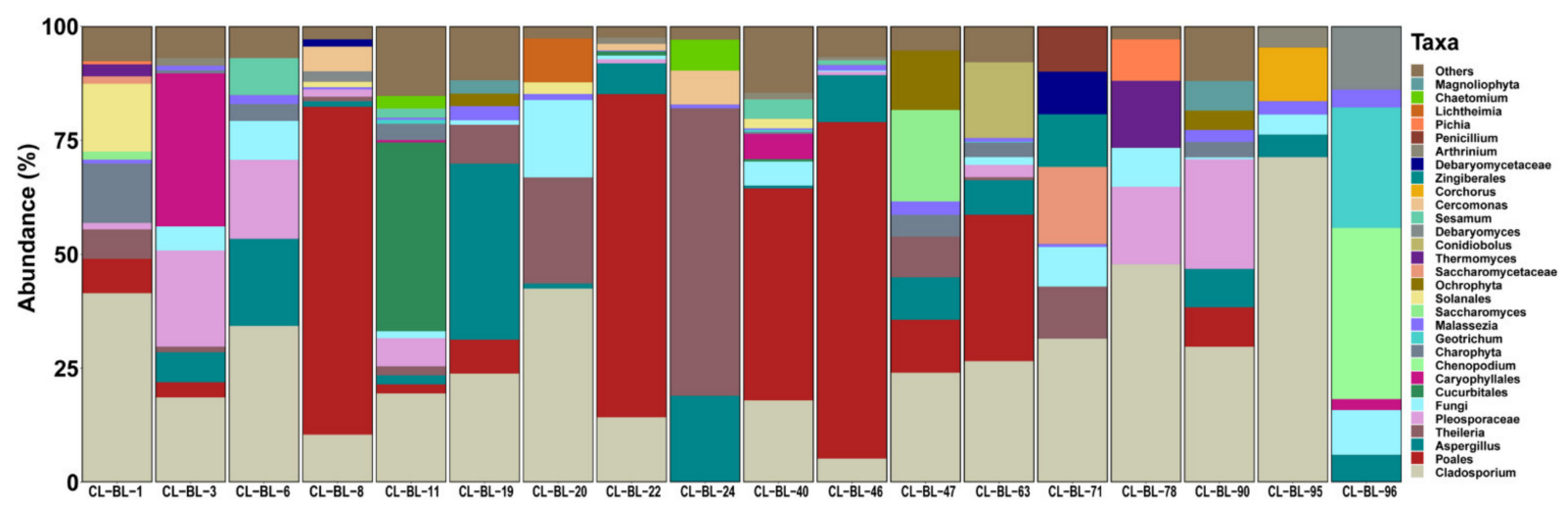

Figure 2. Relative abundance of eukaryotic genera detected in 18 camel blood samples. Each bar represents the eukaryotic taxa detected in one camel sample. The sample ID is provided on the bottom of each bar.

\subsection{Conventional Polymerase Chain Reaction (PCR) and Phylogenetic Relationships}

We found that 29\% (29/100) of the camels were positive by PCR targeting 16S rDNA of Anaplasmataceae (EHR-PCR). Partial gene sequences of the $16 \mathrm{~S}$ rDNA from the 29 positive individuals were $99.7 \%$ (two samples) and $100 \%$ (27 samples) identical to Candidatus Anaplasma camelii (MT510533) from a dromedary camel in Laisamis, Kenya. The maximum likelihood (ML) phylogenetic tree based on the $16 \mathrm{~S}$ rDNA sequences showed that Anaplasma sp. detected from this study clustered with the previously published Candidatus A. camelii and Anaplasma platys (Figure 3).

The partial sequences of the citrate synthase (gltA) gene obtained from 11 samples were $78.7 \%$ similar to A. platys (MH716422) from a tick in Shaanxi Province, China and and $77.4 \%$ to A. platys strain S3 (CP046391) from a dog in Saint Kitts and Nevis. The ML phylogenetic tree based on the gltA gene sequences showed the partial sequences from Anaplasma-positive samples formed an independent cluster separated from the other Anaplasma spp. (Figure 4).

The partial sequences of the heat-shock protein (groEL) gene obtained from 11 Anaplasmapositive samples showed $99-100 \%$ identity to each other. These sequences showed $88.3 \%$ and $86.3 \%$ identity to A. platys (MH716435) found from a Rhipicephalus microplus tick from China and (CP046391) and a dog in Saint Kitts and Nevis, respectively. The obtained sequences were all clustered together in a separate clade from other Anaplasma spp. in the ML phylogenetic analysis (Figure 5). 


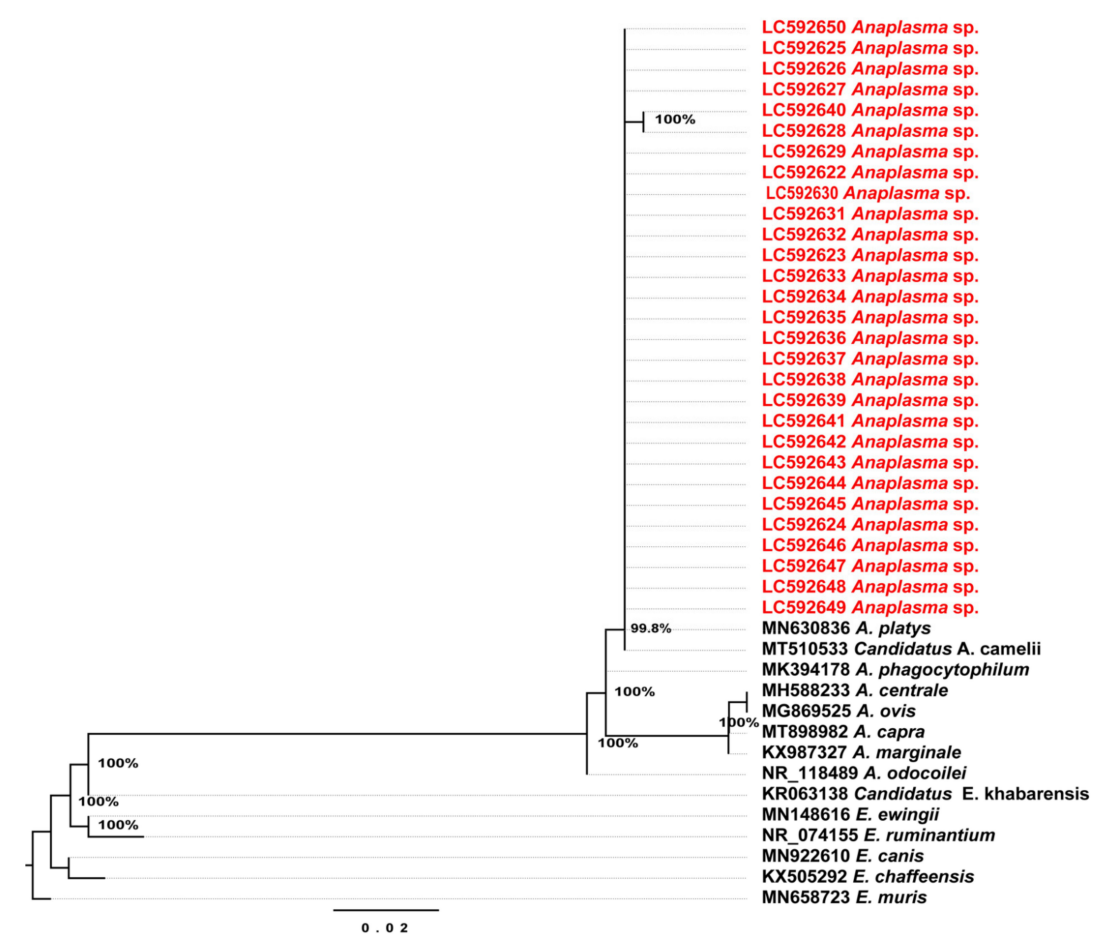

Figure 3. Phylogenetic tree based on the 16S rDNA sequences of Anaplasma and Ehrlichia. The tree was constructed by the maximum likelihood (ML) method based on the HKY85 model (Hasegawa-Kishino-Yano, 85) and site heterogeneity model (Invariant Sites) using the PhyML program. Numbers at the nodes are bootstrap values supported from 1000 replications. The scale bar represents 0.02 nucleotide substitutions per nucleotide site. Red font labels indicate GenBank accession numbers of $16 \mathrm{~S}$ rDNA of Candidatus Anaplasma camelii sequences obtained in this study. The tree was rooted to Ehrlichia muris (MN658723).

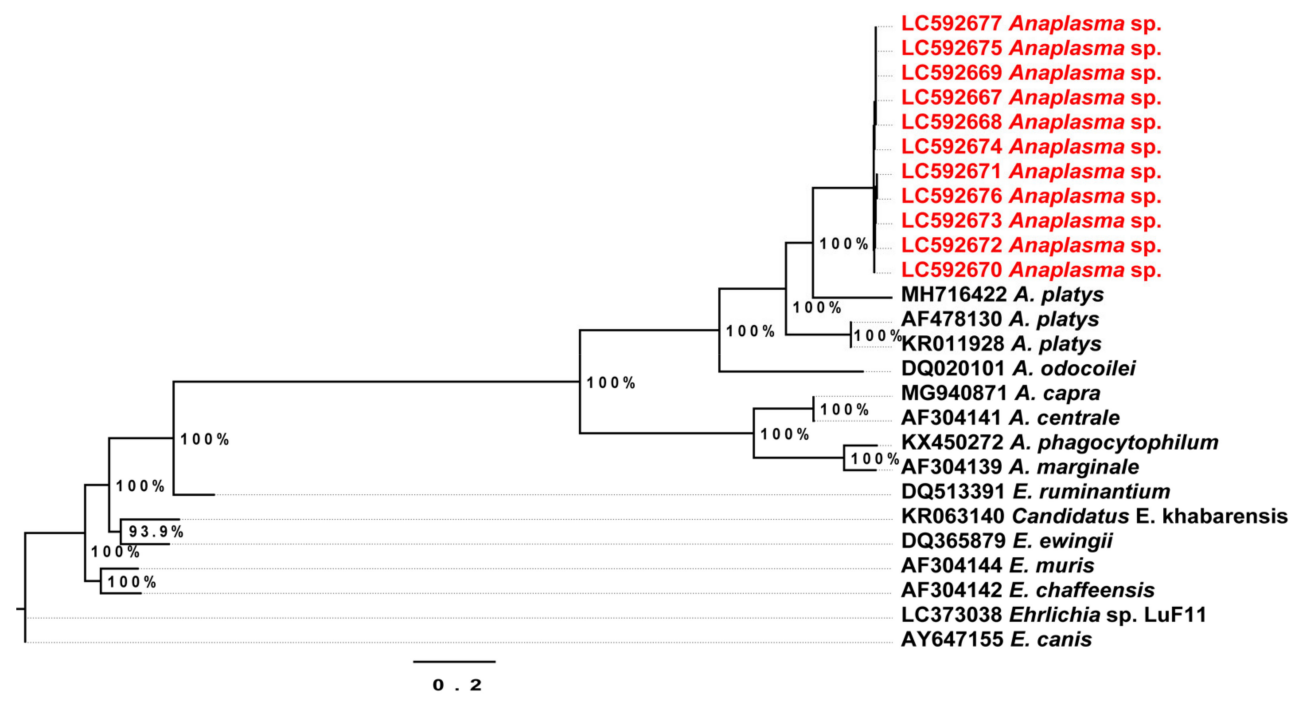

Figure 4. Phylogenetic tree based on the gltA gene sequences of Anaplasma and Ehrlichia. The tree was constructed by the maximum likelihood method based on the GTR (general time reversible) model and site heterogeneity model (Gamma + Invariant Sites) using PhyML program. Numbers at the nodes are bootstrap values supported from 1000 replications. The scale bar represents 0.2 nucleotide substitutions per nucleotide site. Red font labels indicate GenBank accession numbers of the gltA gene of Candidatus Anaplasma camelii sequences from this study. The tree was rooted to Ehrlichia canis (AY647155). 


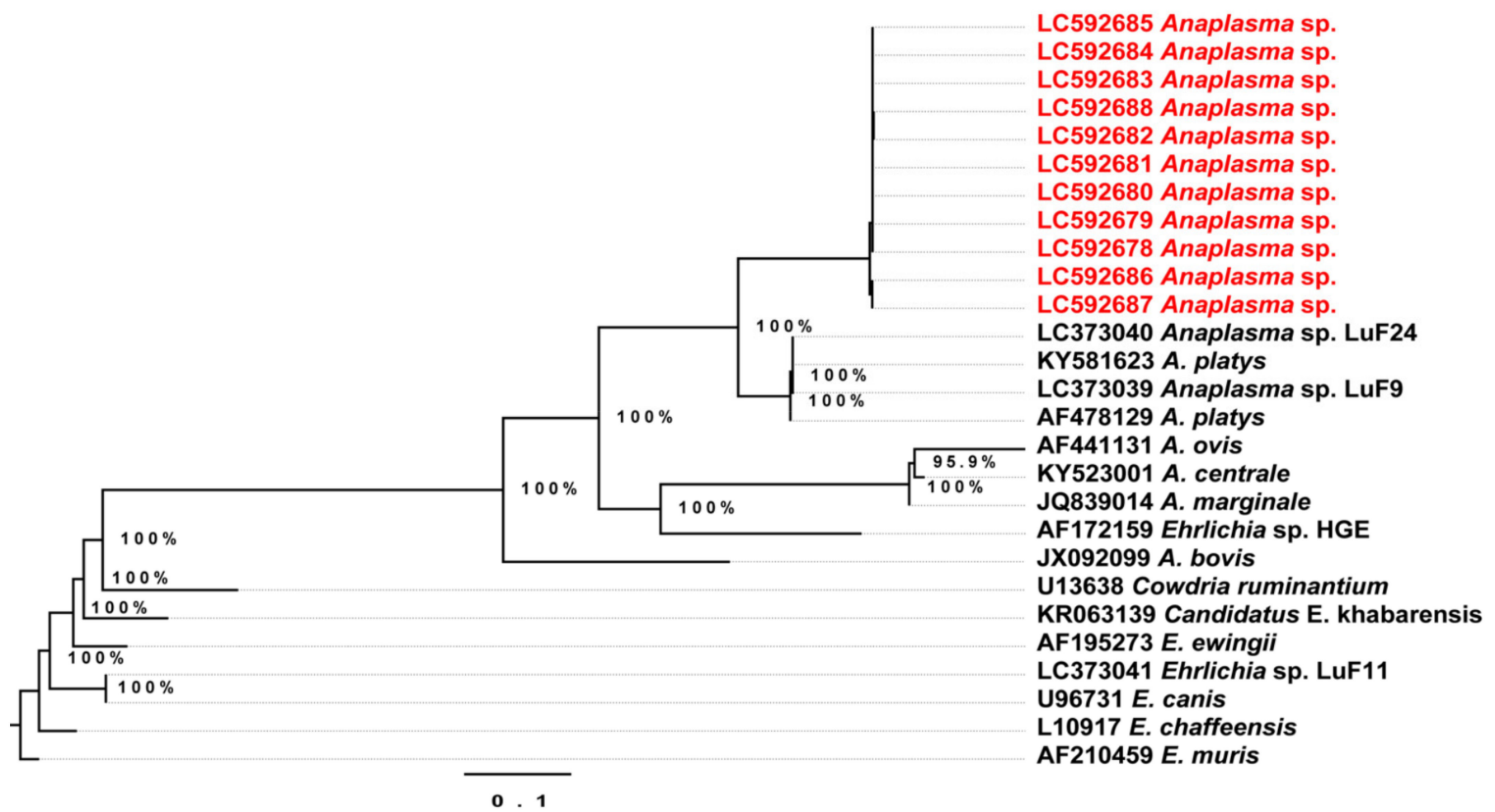

Figure 5. Phylogenetic tree based on the groEL gene sequences of Anaplasma and Ehrlichia. The tree was constructed by the maximum likelihood method based on the GTR (general time reversible) model and site heterogeneity model (Gamma + Invariant Sites) using PhyML program. Numbers at the nodes are bootstrap values supported from 1000 replications. The scale bar represents 0.1 nucleotide substitutions per nucleotide site. Red font labels indicate GenBank accession numbers of the gltA gene of Candidatus Anaplasma camelii obtained in this study. The phylogenetic tree was rooted to Ehrlichia muris (AF210459).

PCR targeting $18 \mathrm{~S}$ rDNA of piroplasma species (RLB-PCR) yielded amplicons in $39 \%(39 / 100)$ of the camels. However, the sequencing analysis revealed that the amplified RLB-PCR products did not belong to piroplasma species and were classified as Cercomonas species.

PCR targeting internal transcribed spacer 1 (ITS1) region of Trypanosoma species (ITS1-PCR) was positive for 19\% (19/100) of the camels. All ITS1-PCR positive samples were also positive by PCR using the primers ILO7957 and ILO8091 (ILO-PCR) targeting the RoTat1.2 VSG region but negative by EVAB-PCR targeting a Tr. evansi type B-specific minicircle sequence, indicating that all Trypanosoma-positive samples were Tr. evansi type A.

\subsection{Phylogenetic Analysis of the Detected Theileria Species}

Conventional PCR targeting the $18 \mathrm{~S}$ rDNA of piroplasma species did not amplify Theileria in our samples. We implemented a phylogenetic analysis of the genus Theileria using the obtained 18S rDNA sequences from NGS. Breifly, features belonging to the genus Theileria were exported and searched in BLAST to identify the species. The assigned taxonomic identities of these features by silva-132-99-nb classifier in QIIME2 were represented as follows: Th. ovis $(n=6)$, Th. separata $(n=2)$, Theileria sp. strain MSD $(n=2)$, Th. annulate $(n=1)$ and Theileria sp. $(n=1)$. Phylogenetic analysis showed that the detected Theileria spp. formed four clades clustered separately with Th. ovis, Th. separata, Th. annulate and Th. mutans. In addition, one Theileria sequence (LC592660) did not form a clade with Theileria sequences available in GenBank (Figure 6). 


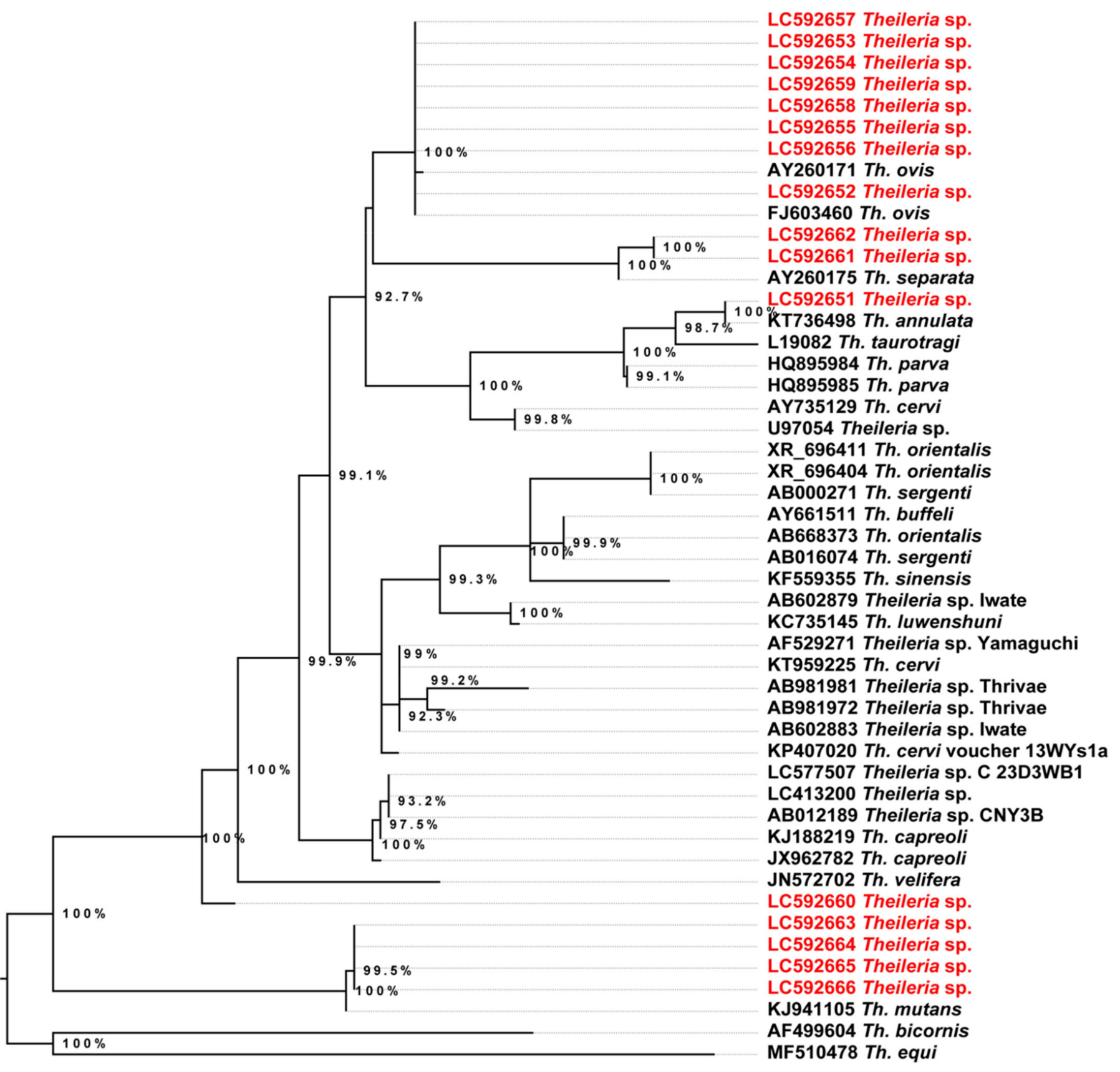

0.03

Figure 6. Phylogenetic tree based on the $18 \mathrm{~S}$ rDNA sequences of Theileria. The tree was constructed by the maximum likelihood method based on the GTR (general time reversible) model and site heterogeneity model (Gamma + Invariant Sites) using PhyML program. Numbers at the nodes are bootstrap values supported from 1000 replications. The scale bar represents 0.03 nucleotide substitutions per nucleotide site. Red font labels indicate GenBank accession numbers of the $18 \mathrm{~S}$ rDNA sequences of Theileria spp. obtained in this study. The tree was rooted to Theileria equi (MF510478).

\subsection{Comparison of Next-Generation Sequencing (NGS)-Based and Conventional PCR Results}

Our results showed that the detection rates of Anaplasma and Theileria were higher using the NGS-based approach than the conventional PCR method. Anaplasma and Theileria were detected in 11 and 10 samples, respectively out of 18 samples using NGS. Conventional PCR was able to detect Anaplasma in 5 out of the 11 samples from which Anaplasma were detected by NGS-based approach. No Theileria spp. were detected by conventional PCR. 
However, conventional PCR could detect Tr. evansi in the examined camel blood samples that were negative for this parasite by NGS-based approach (Table 2).

Table 2. A comparison of results from next-generation sequencing (NGS)-based and conventional polymerase chain reaction (PCR)-based methods in detecting Anaplasma spp., Theileria spp. and Trypanosoma evansi in camel blood samples.

\begin{tabular}{|c|c|c|c|c|c|c|c|c|}
\hline \multirow[b]{2}{*}{ Sample ID } & \multicolumn{4}{|c|}{ Anaplasma spp. } & \multicolumn{2}{|c|}{ Theileria spp. } & \multicolumn{2}{|c|}{ Trypanosoma evansi } \\
\hline & $\begin{array}{l}\text { NGS (V3- } \\
\text { V4-PCR) }\end{array}$ & EHR-PCR & gltA-PCR & groEL-PCR & $\begin{array}{c}\text { NGS } \\
\text { (UNonMet- } \\
\text { PCR) }\end{array}$ & RLB-PCR & $\begin{array}{c}\text { NGS } \\
\text { (UNonMet- } \\
\text { PCR) }\end{array}$ & ILO-PCR \\
\hline CL-BL-1 & $\mathrm{N}$ & $\mathrm{N}$ & $\mathrm{N}$ & $\mathrm{N}$ & $\mathrm{P}$ & $\mathrm{N}$ & $\mathrm{N}$ & $\mathrm{N}$ \\
\hline CL-BL-3 & $\mathrm{P}$ & $\mathrm{N}$ & $\mathrm{N}$ & $\mathrm{N}$ & $\mathrm{P}$ & $\mathrm{N}$ & $\mathrm{N}$ & $\mathrm{N}$ \\
\hline CL-BL-6 & $\mathrm{N}$ & $\mathrm{N}$ & $\mathrm{N}$ & $\mathrm{N}$ & $\mathrm{N}$ & $\mathrm{N}$ & $\mathrm{N}$ & $\mathrm{N}$ \\
\hline CL-BL-8 & $\mathrm{N}$ & $\mathrm{N}$ & $\mathrm{N}$ & $\mathrm{N}$ & $\mathrm{P}$ & $\mathrm{N}$ & $\mathrm{N}$ & $\mathrm{P}$ \\
\hline CL-BL-11 & $\mathrm{P}$ & $\mathrm{N}$ & $\mathrm{N}$ & $\mathrm{N}$ & $\mathrm{P}$ & $\mathrm{N}$ & $\mathrm{N}$ & $\mathrm{N}$ \\
\hline CL-BL-19 & $\mathrm{N}$ & $\mathrm{N}$ & $\mathrm{N}$ & $\mathrm{N}$ & $\mathrm{P}$ & $\mathrm{N}$ & $\mathrm{N}$ & $\mathrm{P}$ \\
\hline CL-BL-20 & $\mathrm{P}$ & $\mathrm{N}$ & $\mathrm{N}$ & $\mathrm{N}$ & $\mathrm{P}$ & $\mathrm{N}$ & $\mathrm{N}$ & $\mathrm{N}$ \\
\hline CL-BL-22 & $\mathrm{N}$ & $\mathrm{N}$ & $\mathrm{N}$ & $\mathrm{N}$ & $\mathrm{N}$ & $\mathrm{N}$ & $\mathrm{N}$ & $\mathrm{N}$ \\
\hline CL-BL-24 & $\mathrm{P}$ & $\mathrm{N}$ & $\mathrm{N}$ & $\mathrm{N}$ & $\mathrm{P}$ & $\mathrm{N}$ & $\mathrm{N}$ & $\mathrm{N}$ \\
\hline CL-BL-40 & $\mathrm{P}$ & $\mathrm{P}$ & $\mathrm{P}$ & $\mathrm{P}$ & $\mathrm{N}$ & $\mathrm{N}$ & $\mathrm{N}$ & $\mathrm{P}$ \\
\hline CL-BL-46 & $\mathrm{P}$ & $\mathrm{P}$ & $\mathrm{P}$ & $\mathrm{P}$ & $\mathrm{N}$ & $\mathrm{N}$ & $\mathrm{N}$ & $\mathrm{P}$ \\
\hline CL-BL-47 & $\mathrm{N}$ & $\mathrm{N}$ & $\mathrm{N}$ & $\mathrm{N}$ & $\mathrm{P}$ & $\mathrm{N}$ & $\mathrm{N}$ & $\mathrm{P}$ \\
\hline CL-BL-63 & $\mathrm{P}$ & $\mathrm{N}$ & $\mathrm{N}$ & $\mathrm{N}$ & $\mathrm{P}$ & $\mathrm{N}$ & $\mathrm{N}$ & $\mathrm{N}$ \\
\hline CL-BL-71 & $\mathrm{N}$ & $\mathrm{N}$ & $\mathrm{N}$ & $\mathrm{N}$ & $\mathrm{P}$ & $\mathrm{N}$ & $\mathrm{N}$ & $\mathrm{N}$ \\
\hline CL-BL-78 & $\mathrm{P}$ & $\mathrm{N}$ & $\mathrm{N}$ & $\mathrm{N}$ & $\mathrm{N}$ & $\mathrm{N}$ & $\mathrm{N}$ & $\mathrm{N}$ \\
\hline CL-BL-90 & $\mathrm{P}$ & $\mathrm{P}$ & $\mathrm{P}$ & $\mathrm{P}$ & $\mathrm{N}$ & $\mathrm{N}$ & $\mathrm{N}$ & $\mathrm{P}$ \\
\hline CL-BL-95 & $\mathrm{P}$ & $\mathrm{P}$ & $\mathrm{P}$ & $\mathrm{P}$ & $\mathrm{N}$ & $\mathrm{N}$ & $\mathrm{N}$ & $\mathrm{N}$ \\
\hline CL-BL-96 & $\mathrm{P}$ & $\mathrm{P}$ & $\mathrm{P}$ & $\mathrm{P}$ & $\mathrm{N}$ & $\mathrm{N}$ & $\mathrm{N}$ & $\mathrm{N}$ \\
\hline
\end{tabular}

V3-V4-PCR, PCR targeting the 16S rRNA gene of prokaryotes; EHR-PCR, PCR targeting the 16S rRNA gene of Anaplasmataceae; gltA-PCR, PCR targeting the glt A gene of Anaplasmataceae; groEL-PCR, PCR targeting the groEL gene of Anaplasmataceae; UNonMet-PCR, PCR targeting the 18S rRNA gene of nonmetazoans; RLB-PCR, PCR targeting the $18 \mathrm{~S}$ rRNA gene of apicomplexan protozoa; ILO-PCR, PCR targeting the RoTat1.2 VSG region; N, negative; P, positive.

\section{Discussion}

Sudan and Ethiopia are the main source of camels to Egypt, with more than 750,000 camels imported between 2012 and 2015 [22]. This legal trade has contributed to the introduction of many infectious diseases such as Rift Valley fever (RVF) [23], Middle East respiratory syndrome coronavirus (MERS-CoV) infection [24] and theileriosis [10]. To the best of our knowledge, this study is the first to describe both the prokaryotic and eukaryotic profiles in the blood of camels. Our strategy was to detect potential pathogens by NGSbased approach in the randomly selected camel samples and to confirm the results by testing all camel samples using target-specific conventional PCR assays.

We found that the blood microbiome of camels tested in this study is dominated by Proteobacteria which is different from the dominant bacterial phyla in the gut microbiome of flightless mammals (Bacteroidetes) $[25,26]$. This can be attributed to the high abundance of features belonging to the family Anaplasmataceae that represented the 4th dominating Proteobacteria in our samples after Pseudomonadaceae, Burkholderiaceae and Xanthobacteraceae (Table S1). There are several potential sources for blood microbes in mammals. For example, it was found that bacteria can be translocated from the gastrointestinal tract to the blood through the intestinal epithelium [27]. However, it was demonstrated that the 
microbiome of human blood in healthy individuals is more similar to those of skin and oral cavity as opposed to the gut microbiome [28]. The translocation of bacteria from the skin and oral cavity to the blood likely occurs through open wounds. In addition, it is also possible that ticks introduce nonpathogenic microbes into the blood stream of camels as previously described in mice [29]. In addition, many other insects including mosquitoes, lice, fleas and true bugs can introduce several microorganisms [30]. However, there is still a possibility that environmental bacteria might have been introduced during sampling and laboratory procedures. Therefore, more experimental investigations are required to confirm the presence of these bacteria in camel blood by employing culture-based and target specific PCR-based methods.

Despite the detection of several eukaryotes using our NGS-based approach, we could not succeed in the complete elimination of camel-derived sequences. This caused the dominance of Metazoa (mean abundance of $72.9 \%$ before removing contaminants) in our samples, suggesting that increasing the depth of sequencing can obtain more eukaryotic members if they exist [13]. However, we were able to identify five different Theileria spp. using this NGS approach for the first time in camels. Moreover, it facilitated the detection of coinfections between several Theileria species (Table 1). The results of our study suggest that imported camels from Sudan could introduce several Theileria spp. to domestic animals in Egypt through the spillover effect. Recent studies reported Th. ovis, Th. separata, Th. annulate and Th. lestoquardi from domestic animals in Sudan [31,32]. Other studies reported that Th. annulate, Th. lestoquardi, Th. equi, Th. ovis and Th. velifera were detected in Hy. anatolicum, Hy. Impeltatum and Amblyomma lepidum [33]. These tick species can infest camels, cattle and sheep [4,34,35], suggesting that a possible transmission of these Theileria spp. may occur among the different livestock through tick vectors in Sudan. Moreover, several undescribed Theileria spp. were detected in camels [10] as well as Th. annulata from cattle in Egypt in 2014 [36]. Interestingly, one of the two detected undescribed Theileria spp. is closely related to Th. mutans while the other is separated from other Theileria spp. on our phylogenetic analysis (Figure 6). Although these Theileria spp. have not been reported before in Egypt, both were detected in camels from Ethiopia [37]. In this study, all Theileria spp. were detected from two or more camel samples except for one Theileria sp. and Th. annulata that were detected from only one sample each (CL-BL-1 and CL-BL-19, respectively). The number of Theileria reads obtained for these samples was 65 and 314, suggesting that they were not false positives. More investigations are required to explore the prevalence of the newly detected Theileria species in camels and ticks.

Although previous studies reported the detection of Th. annulata, Th. equi and Th. ovis in camel blood using conventional PCRs [9,38,39], our RLB-PCR assay did not work for the samples that were Theileria-positive by the NGS-based approach. One possibility is the presence of other eukaryotes that can be amplified by the same primer set. In fact, most of the sequences from RLB-PCR products were classified to the genus Cercomonas by Sanger sequencing method. To overcome this cross-reactivity issue, RLB-PCR products can be subjected to NGS. This strategy was applied to detect several Theileria spp. in African buffalo from South Africa [40] and piroplasm populations in wildlife and cattle in Zambia [41].

Tr. evansi type A was one of the most common parasites detected in camel blood in our study. Our NGS-based approach was not successful in detecting Trypanosoma spp. in the examined samples that were positive by conventional PCR. This is possibly due to a sequence mismatch between UNonMet-PCR primers and Tr. evansi $18 \mathrm{~S}$ rDNA. We found that the forward primer (18S-EUK581-F) has a single nucleotide mismatch with the $18 \mathrm{~S}$ rDNA sequences of Tr. evansi in GenBank. In addition, the failure of detecting Tr. evansi by NGS might be due to low parasitic load in the samples. Moreover, the high abundance of host DNA fragments can also contribute to hindering the amplification of Tr. evansi. Therefore, further investigations and experimental studies are required to improve this approach. 
The prevalence of Tr. evansi infections detected in this study (19\%) differed from what was previously published in Egypt $[39,42,43]$, which reported extremely different prevalence in camels ranging from $4.7 \%$ [42] to $71 \%$ [43]. Although both studies used molecular techniques to detect this parasite from the blood of camels, the large difference in prevalence may be due to variation in geographic location of sample collection sites.

There are several studies reporting Candidatus A. camelii in camels from Saudi Arabia [44], Kenya [45], Nigeria [7], Morocco [46] and Iran [47]. Our study showed that 29\% of the camels imported from Sudan were infected with Candidatus A. camelii. In fact, this recently described bacterium has also been reported from cattle (Bos taurus) and deer (Rusa timorensis) in Malaysia [48], suggesting that it could spillover to a wide range of animals in Egypt. In a previous study, antibodies against Anaplasma were detected in camel blood in Egypt, however, species identification was not attempted [49]. The high sequence similarity of the $16 \mathrm{~S}$ rDNA of Candidatus A. camelii and A. platys makes it difficult to describe the evolutionary relationship and host range of both species. This study provided partial sequences of $g l t A$ and groEL genes for the first time from Candidatus A. camelii. The sequences obtained were $78.7 \%$ and $88.3 \%$ identical to the glt $A$ and groEL partial gene sequences of $A$. platys, respectively, suggesting that both genes are useful markers to differentiate between the two closely related Anaplasma species. Although the prevalence of Candidatus A. camelii was relatively high, this study could not confirm whether this bacterium can pose a potential veterinary or zoonotic risk.

Metagenomics of the host-associated eukaryotic populations has been challenging primarily because most universal primers amplify the 18S rDNA of host animals rather than those of animal-associated eukaryotes [13]. In the present study, we applied UNonMet-PCR to reduce the amplicons from metazoan, that is, camel. Other promising methods, which can be applied through exploring the eukaryotic microorganisms in mammalian hosts, include blocking primers with a C3 spacer addition at the $3^{\prime}$ end. This blocking method was also successfully used to bind the host DNA, resulting in blocking its amplification by inhibiting the elongation of the primer [50]. In addition, peptide-nucleic acid (PNA) blockers have been used to inhibit the amplification of 185 rDNA of non-target organisms including mosquitoes [51]. PNA blockers were also successful in increasing the sequence coverage of coral microbial communities by reducing host contamination [52]. These methods may facilitate metagenomic studies of host-associated eukaryotes within mammalian blood.

\section{Conclusions}

This study implemented a metagenomic investigation targeting the blood circulating prokaryotes and eukaryotes in camels, which could be used in other species of mammals. We revealed that the camels imported from Sudan were infected with a total of seven pathogens or potential pathogens, including Tr. evansi type A, Candidatus A. camelii, Th. ovis, Th. separata, Th. annulata, Th. mutans and undescribed Theileria species. In addition, we provided gltA and groEL partial gene sequences of Candidatus A. camelii that can be used to differentiate this pathogen from $A$. platys. Our study results support the hybrid approach to characterize the microbe of interest in mammals using NGS and conventional PCR combined with Sanger sequencing as was found in humans [53]. This will increase our understanding of the risks posed by importing animals and the accompanying tickborne pathogens.

\section{Materials and Methods}

\subsection{Camel Blood Samples and DNA Extraction}

Blood samples were collected from the jugular vein of 100 camels from Abu Simbel near the Egypt-Sudan border. All camels were adult males imported from Sudan and kept in quarantine during the sampling process. The blood samples were collected on Na-EDTA tubes and DNA was extracted using innuPREP Blood DNA Mini Kit (Analytik Jena AG, Jena, Germany) following the manufacturer's recommendations and stored at $-20{ }^{\circ} \mathrm{C}$ until analyzed. 


\section{2. $16 \mathrm{~S}$ rDNA and $18 \mathrm{~S}$ rDNA Amplification and Illumina MiSeq Sequencing}

A total of 18 camel blood samples were used for investigation by a metagenomic approach. Since all camels showed no clinical signs, we selected these samples randomly. We performed PCR targeting the V3-V4 region of the $16 \mathrm{~S}$ rDNA of prokaryotes using Illumina barcoded primers (San Diego, CA, USA) Illumina_16S_341F and Illumina_16S_805R as recommended by Illumina (Table 3 ).

Table 3. List of PCR primers used in this study.

\begin{tabular}{|c|c|c|c|c|}
\hline PCR Name & Primer Name & Primer Sequence $\left(5^{\prime}-3^{\prime}\right)$ & $\begin{array}{c}\text { Annealing } \\
\text { Temp/Extension Time }\end{array}$ & Reference \\
\hline \multirow[t]{2}{*}{ V3-V4-PCR } & Illumina_16S_341F & $\begin{array}{c}\text { TCGTCGGCAGCGTCAGATGTGTA } \\
\text { TAAGAGACAGCCTACGGGNGG } \\
\text { CWGCAG }\end{array}$ & \multirow[t]{2}{*}{$55^{\circ} \mathrm{C} / 30 \mathrm{~s}$} & \multirow[t]{2}{*}[54]{} \\
\hline & Illumina_16S_805R & $\begin{array}{c}\text { GTCTCGTGGGCTCGGAGATGTGTA } \\
\text { TAAGAGACAGGACTACHVGGGTAT } \\
\text { CTAATCC }\end{array}$ & & \\
\hline \multirow{2}{*}{ UNonMet-PCR } & 18S-EUK581-F & GTGCCAGCAGCCGCG & \multirow{2}{*}{$62{ }^{\circ} \mathrm{C} / 30 \mathrm{~s}$} & \multirow{2}{*}[22]{} \\
\hline & 18S-EUK1134-R & TTTAAGTTTCAGCCTTGCG & & \\
\hline \multirow[t]{2}{*}{ V4-PCR } & Illumina_E572F & $\begin{array}{c}\text { TCGTCGGCAGCGTCAGATGTGTA } \\
\text { TAAGAGACAGCYGCGGTAATTCC } \\
\text { AGCTC }\end{array}$ & \multirow[t]{2}{*}{$55^{\circ} \mathrm{C} / 30 \mathrm{~s}$} & \multirow[t]{2}{*}{ [23] } \\
\hline & Illumina_E1009R & $\begin{array}{l}\text { GTCTCGTGGGCTCGGAGAT } \\
\text { GTGTATAAGAGACAGAY } \\
\text { GGTATCTRATCRTCTTYG }\end{array}$ & & \\
\hline \multirow{2}{*}{ RLB-PCR } & RLB-F2 & GACACAGGGAGGTAGTGACAAG & \multirow{2}{*}{$54^{\circ} \mathrm{C} / 15 \mathrm{~s}$} & \multirow{2}{*}{ [55] } \\
\hline & RLB-R2 & CTAAGAATTTCACCTCTGACAGT & & \\
\hline \multirow{2}{*}{ ITS1-PCR } & ITS1-CF & CCGGAAGTTCACCGATATTG & \multirow{2}{*}{$52{ }^{\circ} \mathrm{C} / 15 \mathrm{~s}$} & \multirow{2}{*}{ [56] } \\
\hline & ITS1-BR & TTGCTGCGTTCTTCAACGAA & & \\
\hline \multirow{2}{*}{ EHR-PCR } & EHR16SD & GGTACCYACAGAAGAAGTCC & \multirow{2}{*}{$61{ }^{\circ} \mathrm{C} / 15 \mathrm{~s}$} & \multirow{2}{*}{ [57] } \\
\hline & EHR16SR & TAGCACTCATCGTTTACAGC & & \\
\hline \multirow{2}{*}{ gltA-PCR (1st) } & $\mathrm{F} 4 \mathrm{~b}$ & CCGGGTTTTATGTCTACTGC & \multirow{2}{*}{$55^{\circ} \mathrm{C} / 15 \mathrm{~s}$} & \multirow{2}{*}[58]{} \\
\hline & $\mathrm{R} 1 \mathrm{~b}$ & CGATGACCAAAACCCAT & & \\
\hline \multirow{2}{*}{ gltA-PCR (2nd) } & EHR-CS136F & TTYATGTCYACTGCTGCKTG & \multirow{2}{*}{$50^{\circ} \mathrm{C} / 15 \mathrm{~s}$} & \multirow{2}{*}{ [58] } \\
\hline & EHR-CS778R & GCNCCMCCATGMGCTGG & & \\
\hline \multirow{2}{*}{ groEL-PCR (1st) } & HS1-F & CGYCAGTGGGCTGGTAATGAA & \multirow{2}{*}{$54^{\circ} \mathrm{C} / 15 \mathrm{~s}$} & \multirow{2}{*}[59,60]{} \\
\hline & HS6-R & CCWCCWGGTACWACACCTTC & & \\
\hline \multirow{2}{*}{ groEL-PCR (2nd) } & HS3-F & ATAGTYATGAAGGAGAGTGAT & \multirow{2}{*}{$50{ }^{\circ} \mathrm{C} / 15 \mathrm{~s}$} & \multirow{2}{*}[60,61]{} \\
\hline & HSV-R & TCAACAGCAGCTCTAGTWG & & \\
\hline \multirow{2}{*}{ ILO-PCR } & ILO7957 & GCCACCACGGCGAAAGAC & \multirow{2}{*}{$52{ }^{\circ} \mathrm{C} / 15 \mathrm{~s}$} & \multirow{2}{*}[62]{} \\
\hline & ILO8091 & TAATCAGTGTGGTGTGC & & \\
\hline \multirow{2}{*}{ EVAB-PCR } & EVAB1 & CACAGTCCGAGAGATAGAG & $60^{\circ} \mathrm{C} / 15 \mathrm{~s}$ & {$[63]$} \\
\hline & EVAB2 & CTGTACTCTACATCTACCTC & & \\
\hline
\end{tabular}

The V4 region of the 18S rDNA of eukaryotes was amplified using the following nested PCR assays. The 1st PCR (UNonMet-PCR) reaction was performed to decrease the amplification of host DNA fragments in the blood samples using the primers 18S-EUK581-F and 18S-EUK1134-R [64]. The resulting PCR products were used as DNA templates for a 2nd PCR using the primers Illumina_E572F and Illumina_E1009R [65]. Each PCR reaction 
contained $12.5 \mu \mathrm{L}$ of $2 \times$ KAPA HiFi HotStart ReadyMix (Kapa BioSystems, Wilmington, MA, USA); $5 \mu \mathrm{L}$ of each primer and $2.5 \mu \mathrm{L}$ of the genomic DNA samples or 1st PCR products. The UNonMet-PCR included 15 cycles followed by the 2nd PCR using 30 cycles as shown in Table 3. PCR results were visualized by electrophoresis on 1.5\% agarose gel stained with Gel-RedTM (Biotium, Hayward, CA, USA). Illumina sequencing libraries were prepared by purifying the amplicons using AMPure XP (Beckman Coulter Life Sciences, IN, USA) and sequencing adapters and index sequences were added using the Nextera XT Index Kit (Illumina). The sequencing run was conducted with a MiSeq Reagent Kit v3 (600 cycles) on an Illumina MiSeq device according to the manufacturer's instructions.

\subsection{Illumina Data Processing}

The resulting fastq files were analyzed in QIIME2 (version 2019.10.0) [66]. The forward and reverse reads were merged into one sequence and the obtained sequences were quality checked and filtered. A feature table was established using the Divisive Amplicon Denoising Algorithm 2 (DADA2) pipeline [67]. We used silva-132-99-nb classifier to assign taxonomy to each ASV. Differential abundances of the detected taxonomic groups were visualized using the taxa_heatmap function in the qiime2R package in $R$ (version 2.13.0). Contaminants were filtered in $\mathrm{R}$ (version 3.4.1) by using the prevalence-based method in Decontam $R$ package by setting the threshold $=0.5$ and indicating the negative control sample as "negative". [68]. Indicated contaminants were filtered out from all samples in QIIME2. Raw sequence data have been deposited in DNA Data Bank of Japan (DDBJ) sequence read archive with an accession number of DRA011269.

\subsection{Conventional PCR and Sanger Sequencing}

A total of 100 camel blood samples were tested by conventional PCRs targeting $18 \mathrm{~S}$ rDNA (RLB-PCR), ITS1 region and 16S rDNA (EHR-PCR) of apicomplexan protozoa, trypanosomes and Anaplasmataceae, respectively. Trypanosoma-positive samples were further examined for Tr. evansi by ILO-PCR using the primers ILO7957 and ILO8091 [16] and by EVAB-PCR using the primers EVAB1 and EVAB2 [15]. Anaplasma-positive samples were further characterized by amplifying a $650 \mathrm{bp}$ and $1100 \mathrm{bp}$ segments of $g l t A$ and groEL genes, respectively, as previously described [69].

PCR reactions consisted of a $25 \mu \mathrm{L}$ mixture of $12.5 \mu \mathrm{L}$ of $2 \times$ Gflex PCR Buffer, $0.5 \mu \mathrm{L}$ of Tks Gflex DNA Polymerase (1.25 units $/ \mu \mathrm{L}$ ) (TaKaRa Bio Inc., Shiga, Japan), $0.5 \mu \mathrm{L}$ of each primer, $1.0 \mu \mathrm{L}$ of template DNA and molecular grade water (Table 3). The PCR System 9700 (Applied Biosystems, Foster City, CA, USA) was used to run an initial denaturation at $94{ }^{\circ} \mathrm{C}$ for $1 \mathrm{~min}$, followed by 40 cycles of denaturation at $94{ }^{\circ} \mathrm{C}$ for $10 \mathrm{~s}$, annealing (Table 3), extension at $68^{\circ} \mathrm{C}$ for $15 \mathrm{~s}$ and final extension at $68^{\circ} \mathrm{C}$ for $5 \mathrm{~min}$. The primer sequences used in the present study are listed in Table 3. PCR products were analyzed by electrophoresis in $1 \%$ agarose gel stained with Gel-Red (Biotium, Hayward, CA, USA) and visualized under an ultraviolet (UV) light.

The positive PCR products that were obtained from RLB-PCR, EHR-PCR, gltA-PCR and groEL-PCR were purified by ExoSAP-IT PCR Product Cleanup Reagent (Applied Biosystems, Foster City, CA, USA) and sequenced using the BigDye Terminator v3.1 Cycle Sequencing Kit (Applied Biosystems) and an ABI Prism 3130xl genetic analyzer (Applied Biosystems).

\subsection{Phylogenetic Analysis}

The obtained $18 \mathrm{~S}$ rDNA features belonging to genus Theileria were exported from QIIME2 (version 2019.10.0) [66] to Geneious v10.2.6 (Biomatters Ltd., Auckland, New Zealand). In addition, the obtained sequences from Sanger sequencing were also assembled in Geneious v10.2.6 (Biomatters Ltd., Auckland, New Zealand) and the primer regions were removed. We compared the obtained sequences to those in published databases using the nucleotide basic local alignment search tool (BLASTn, https:/ /blast.ncbi.nlm.nih.gov/ Blast.cgi?PAGE_TYPE=BlastSearch) (accessed on 12 December 2020). The sequences were 
aligned using MAFFT v7.450 software [70] and the best fit model for the analysis was determined using MEGA $X$ software [71] and phylogenetic trees were constructed using the maximum likelihood method in PHYML v3.3 software [72].

The sequences obtained in this study were submitted to the DDBJ under the accession numbers: LC592651-LC592666 for 18S rDNA, LC592622-LC592650 for 16S rDNA, LC592667LC592677 for gltA and LC592678-LC592688 for groEL.

Supplementary Materials: The following are available online at https:/ / www.mdpi.com/2076-081 7/10/3/351/s1, Table S1: Summary of the bacterial contaminants detected by Decontam R package. Table S2: Abundance of the genus level taxa of the 16S rDNA sequences obtained from camel blood samples. Table S3: Summary of the eukaryotic contaminants detected by Decontam R package. Table S4: Abundance of the genus level taxa of the 18S rDNA sequences obtained from camel blood samples.

Author Contributions: Conceptualization, W.M.A.M., M.A.M.M. and R.N.; sampling, A.O.A., H.Y.A.H.M. and M.A.O.; methodology, W.M.A.M., J.L.A., D.N., E.C., H.Y.A.H.M. and M.A.M.M.; formal analysis, W.M.A.M., B.S. and M.A.M.M.; writing original draft preparation, W.M.A.M., M.A.M.M.; writing review and editing, W.M.A.M., H.Y.A.H.M., M.A.M.M., N.N. and R.N.; funding acquisition, R.N. All authors have read and agreed to the published version of the manuscript.

Funding: This research was supported by KAKENHI (16H06431, 19H03118, 19F19097, 20K21358 and 20KK0151) and the Japan Program for Infectious Diseases Research and Infrastructure (20wm0225016j0001) from the Japan Agency for Medical Research and Development (AMED).

Institutional Review Board Statement: Permission for sampling blood from camels was obtained from the Animal Experiment and Research Committee, Faculty of Veterinary Medicine, South Valley University in Egypt with a reference number of RCOE-SVU-3003171. All the procedures were conducted in accordance with the guidelines established by the Animal Experiment Committee of the Graduate School of Veterinary Medicine, Hokkaido University (Sapporo, Japan).

Data Availability Statement: Raw sequence data have been deposited in the DNA Data Bank of Japan (DDBJ) Sequence Read Archive with an accession number of DRA011269.

Acknowledgments: We would like to thank to all collaborators who supported the collection of camel blood in Egypt.

Conflicts of Interest: The authors declare no conflict of interest. The funders had no role in the design of the study; in the collection, analyses, or interpretation of data; in the writing of the manuscript, or in the decision to publish the results.

\section{References}

1. Burger, P.A.; Ciani, E.; Faye, B. Old World camels in a modern world-A balancing act between conservation and genetic improvement. Anim. Genet. 2019, 50, 598-612. [CrossRef] [PubMed]

2. Chuluunbat, B.; Charruau, P.; Silbermayr, K.; Khorloojav, T.; Burger, P.A. Genetic diversity and population structure of Mongolian domestic Bactrian camels (Camelus bactrianus). Anim. Genet. 2014, 45, 550-558. [CrossRef]

3. Alanazi, A.D.; Nguyen, V.L.; Alyousif, M.S.; Manoj, R.R.S.; Alouffi, A.S.; Donato, R.; Sazmand, A.; Mendoza-Roldan, J.A.; Dantas-Torres, F.; Otranto, D. Ticks and associated pathogens in camels (Camelus dromedarius) from Riyadh Province, Saudi Arabia. Parasites Vectors 2020, 13, 110. [CrossRef] [PubMed]

4. Gharbi, M.; Moussi, N.; Jedidi, M.; Mhadhbi, M.; Sassi, L.; Darghouth, M.A. Population dynamics of ticks infesting the one-humped camel (Camelus dromedarius) in central Tunisia. Ticks Tick-Borne Dis. 2013, 4, 488-491. [CrossRef] [PubMed]

5. Azmat, M.; Ijaz, M.; Farooqi, S.H.; Ghaffar, A.; Ali, A.; Masud, A.; Saleem, S.; Rehman, A.; Ali, M.M.; Mehmood, K.; et al. Molecular epidemiology, associated risk factors, and phylogenetic analysis of anaplasmosis in camel. Microb. Pathog. 2018, 123, 377-384. [CrossRef] [PubMed]

6. $\quad$ Bellabidi, M.; Benaissa, M.H.; Bissati-Bouafia, S.; Harrat, Z.; Brahmi, K.; Kernif, T. Coxiella burnetii in camels (Camelus dromedarius) from Algeria: Seroprevalence, molecular characterization, and ticks (Acari: Ixodidae) vectors. Acta Trop. 2020, $206,105443$. [CrossRef]

7. Onyiche, T.E.; Raileanu, C.; Tauchmann, O.; Fischer, S.; Vasic, A.; Schafer, M.; Biu, A.A.; Ogo, N.I.; Thekisoe, O.; Silaghi, C. Prevalence and molecular characterization of ticks and tick-borne pathogens of one-humped camels (Camelus dromedarius) in Nigeria. Parasites Vectors 2020, 13, 428. [CrossRef] 
8. Selmi, R.; Ben Said, M.; Ben Yahia, H.; Abdelaali, H.; Messadi, L. Molecular epidemiology and phylogeny of spotted fever group Rickettsia in camels (Camelus dromedarius) and their infesting ticks from Tunisia. Transbound. Emerg. Dis. 2020, 67, 733-744. [CrossRef]

9. Sazmand, A.; Eigner, B.; Mirzaei, M.; Hekmatimoghaddam, S.H.; Harl, J.; Duscher, G.G.; Fuehrer, H.; Joachim, A. Molecular identification of hemoprotozoan parasites in camels (Camelus dromedarius) of Iran. Iran. J. Parasitol. 2016, 11, 568-573. [PubMed]

10. Youssef, S.Y.; Yasien, S.; Mousa, W.M.; Nasr, S.M.; El-Kelesh, E.A.; Mahran, K.M.; Abd-El-Rahman, A.H. Vector identification and clinical, hematological, biochemical, and parasitological characteristics of camel (Camelus dromedarius) theileriosis in Egypt. Trop. Anim. Health Prod. 2015, 47, 649-656. [CrossRef] [PubMed]

11. Del Campo, J.; Pons, M.J.; Herranz, M.; Wakeman, K.C.; Del Valle, J.; Vermeij, M.J.A.; Leander, B.S.; Keeling, P.J. Validation of a universal set of primers to study animal-associated microeukaryotic communities. Environ. Microbiol. 2019, 21, 3855-3861. [CrossRef] [PubMed]

12. Weinstock, G.M.; Goldberg, B.; Ledeboer, N.; Rubin, E.; Sichtig, H.; Geyer, C. Applications of Clinical Microbial Next-Generation Sequencing. Am. Soc. Microbiol. 2016. [CrossRef]

13. Wilcox, J.J.S.; Hollocher, H. Unprecedented symbiont eukaryote diversity is governed by internal trophic webs in a wild non-human primate. Protist 2018, 169, 307-320. [CrossRef]

14. Carnegie, R.B.; Meyer, G.R.; Blackbourn, J.; Cochennec-Laureau, N.; Berthe, F.C.; Bower, S.M. Molecular detection of the oyster parasite Mikrocytos mackini, and a preliminary phylogenetic analysis. Dis. Aquat. Org. 2003, 54, 219-227. [CrossRef] [PubMed]

15. Ondrejicka, D.A.; Locke, S.A.; Morey, K.; Borisenko, A.V.; Hanner, R.H. Status and prospects of DNA barcoding in medically important parasites and vectors. Trends Parasitol. 2014, 30, 582-591. [CrossRef] [PubMed]

16. Huggins, L.G.; Koehler, A.V.; Ng-Nguyen, D.; Wilcox, S.; Schunack, B.; Inpankaew, T.; Traub, R.J. A novel metabarcoding diagnostic tool to explore protozoan haemoparasite diversity in mammals: A proof-of-concept study using canines from the tropics. Sci. Rep. 2019, 9, 12644. [CrossRef]

17. Ellis, J.E.; Missan, D.S.; Shabilla, M.; Moschonas, C.; Saperstein, D.; Martinez, D.; Becker, C.V.; Fry, S.E. Comparison of the prokaryotic and eukaryotic microbial communities in peripheral blood from amyotrophic lateral sclerosis, multiple sclerosis, and control populations. Hum. Microbiome J. 2019, 13, 100060. [CrossRef]

18. Castillo, D.J.; Rifkin, R.F.; Cowan, D.A.; Potgieter, M. The healthy human blood microbiome: Fact or fiction? Front. Cell. Infect. Microbiol. 2019, 9, 148. [CrossRef] [PubMed]

19. Sze, M.A.; Tsuruta, M.; Yang, S.W.; Oh, Y.; Man, S.F.; Hogg, J.C.; Sin, D.D. Changes in the bacterial microbiota in gut, blood, and lungs following acute LPS instillation into mice lungs. PLoS ONE 2014, 9, e111228. [CrossRef]

20. Vientos-Plotts, A.I.; Ericsson, A.C.; Rindt, H.; Grobman, M.E.; Graham, A.; Bishop, K.; Cohn, L.A.; Reinero, C.R. Dynamic changes of the respiratory microbiota and its relationship to fecal and blood microbiota in healthy young cats. PLoS ONE 2017, 12, e0173818. [CrossRef] [PubMed]

21. Paisse, S.; Valle, C.; Servant, F.; Courtney, M.; Burcelin, R.; Amar, J.; Lelouvier, B. Comprehensive description of blood microbiome from healthy donors assessed by $16 \mathrm{~S}$ targeted metagenomic sequencing. Transfusion 2016, 56, 1138-1147. [CrossRef] [PubMed]

22. Napp, S.; Chevalier, V.; Busquets, N.; Calistri, P.; Casal, J.; Attia, M.; Elbassal, R.; Hosni, H.; Farrag, H.; Hassan, N.; et al. Understanding the legal trade of cattle and camels and the derived risk of Rift Valley Fever introduction into and transmission within Egypt. PLoS Negl. Trop. Dis. 2018, 12, e0006143. [CrossRef]

23. Ahmed Kamal, S. Observations on rift valley fever virus and vaccines in Egypt. Virol. J. 2011, 8, 532. [CrossRef]

24. Chu, D.K.; Poon, L.L.; Gomaa, M.M.; Shehata, M.M.; Perera, R.A.; Abu Zeid, D.; El Rifay, A.S.; Siu, L.Y.; Guan, Y.; Webby, R.J.; et al. MERS coronaviruses in dromedary camels, Egypt. Emerg. Infect. Dis. 2014, 20, 1049-1053. [CrossRef]

25. Song, S.J.; Sanders, J.G.; Delsuc, F.; Metcalf, J.; Amato, K.; Taylor, M.W.; Mazel, F.; Lutz, H.L.; Winker, K.; Graves, G.R.; et al Comparative analyses of vertebrate gut microbiomes reveal convergence between birds and bats. MBio 2020, 11. [CrossRef]

26. Ley, R.E.; Hamady, M.; Lozupone, C.; Turnbaugh, P.J.; Ramey, R.R.; Bircher, J.S.; Schlegel, M.L.; Tucker, T.A.; Schrenzel, M.D.; Knight, R.; et al. Evolution of mammals and their gut microbes. Science 2008, 320, 1647-1651. [CrossRef] [PubMed]

27. Penders, J.; Thijs, C.; Vink, C.; Stelma, F.F.; Snijders, B.; Kummeling, I.; Van den Brandt, P.A.; Stobberingh, E.E. Factors influencing the composition of the intestinal microbiota in early infancy. Pediatrics 2006, 118, 511-521. [CrossRef]

28. Whittle, E.; Leonard, M.O.; Harrison, R.; Gant, T.W.; Tonge, D.P. Multi-method characterization of the human circulating microbiome. Front. Microbiol. 2019, 9. [CrossRef] [PubMed]

29. Narasimhan, S.; Rajeevan, N.; Liu, L.; Zhao, Y.O.; Heisig, J.; Pan, J.; Eppler-Epstein, R.; Deponte, K.; Fish, D.; Fikrig, E. Gut microbiota of the tick vector Ixodes scapularis modulate colonization of the Lyme disease spirochete. Cell Host Microbe 2014, 15, 58-71. [CrossRef]

30. Laroche, M.; Raoult, D.; Parola, P. Insects and the transmission of bacterial agents. Microbiol. Spectr. 2018, 6. [CrossRef]

31. El Imam, A.H.; Hassan, S.M.; Gameel, A.A.; El Hussein, A.M.; Taha, K.M.; Oosthuizen, M.C. Molecular identification of different Theileria and Babesia species infecting sheep in Sudan. Ann. Parasitol. 2016, 62, 47-54. [CrossRef] [PubMed]

32. Magzoub, A.; El Ghali, A.; Hussien, M.O.; Juma, Y.; Mohammed, S.B. Prevalence of ticks (Acari: Ixodidae) and Theileria lestoquardi in sheep at El Huda and El Nuhud animals production research stations, Sudan. J. Parasit. Dis. 2020. [CrossRef]

33. Springer, A.; Shuaib, Y.A.; Isaa, M.H.; Ezz-Eldin, M.I.; Osman, A.Y.; Yagoub, I.A.; Abdalla, M.A.; Bakiet, A.O.; Mohmed-Noor, S.E.; Schaper, S.; et al. Tick fauna and associated Rickettsia, Theileria, and Babesia spp. in domestic animals in Sudan (north Kordofan and Kassala states). Microorganisms 2020, 8, 1969. [CrossRef] [PubMed] 
34. Shemshad, M.; Shemshad, K.; Sedaghat, M.M.; Shokri, M.; Barmaki, A.; Baniardalani, M.; Rafinejad, J. First survey of hard ticks (Acari: Ixodidae) on cattle, sheep and goats in Boeen Zahra and Takistan counties, Iran. Asian Pac. J. Trop. Biomed. 2012, 2, 489-492. [CrossRef]

35. Bouattour, A.; Darghouth, M.A.; Daoud, A. Distribution and ecology of ticks (Acari: Ixodidae) infesting livestock in Tunisia: An overview of eighth years field collections. Parassitologia 1999, 41 (Suppl. 1), 5-10.

36. Elsify, A.; Sivakumar, T.; Nayel, M.; Salama, A.; Elkhtam, A.; Rizk, M.; Mosaab, O.; Sultan, K.; Elsayed, S.; Igarashi, I.; et al. An epidemiological survey of bovine Babesia and Theileria parasites in cattle, buffaloes, and sheep in Egypt. Parasitol. Int. 2015, 64, 79-85. [CrossRef]

37. Tomassone, L.; Grego, E.; Callà, G.; Rodighiero, P.; Pressi, G.; Gebre, S.; Zeleke, B.; De Meneghi, D. Ticks and tick-borne pathogens in livestock from nomadic herds in the Somali Region, Ethiopia. Exp. Appl. Acarol. 2012, 56, 391-401. [CrossRef]

38. Qablan, M.A.; Sloboda, M.; Jirků, M.; Oborník, M.; Dwairi, S.; Amr, Z.S.; Hořín, P.; Lukeš, J.; Modrý, D. Quest for the piroplasms in camels: Identification of Theileria equi and Babesia caballi in Jordanian dromedaries by PCR. Vet. Parasitol. 2012, 186, 456-460. [CrossRef]

39. Lorusso, V.; Wijnveld, M.; Latrofa, M.S.; Fajinmi, A.; Majekodunmi, A.O.; Dogo, A.G.; Igweh, A.C.; Otranto, D.; Jongejan, F.; Welburn, S.C.; et al. Canine and ovine tick-borne pathogens in camels, Nigeria. Vet. Parasitol. 2016, 228, 90-92. [CrossRef] [PubMed]

40. Glidden, C.K.; Koehler, A.V.; Hall, R.S.; Saeed, M.A.; Coppo, M.; Beechler, B.R.; Charleston, B.; Gasser, R.B.; Jolles, A.E.; Jabbar, A. Elucidating cryptic dynamics of Theileria communities in African buffalo using a high-throughput sequencing informatics approach. Ecol. Evol. 2020, 10, 70-80. [CrossRef] [PubMed]

41. Squarre, D.; Nakamura, Y.; Hayashida, K.; Kawai, N.; Chambaro, H.; Namangala, B.; Sugimoto, C.; Yamagishi, J. Investigation of the piroplasm diversity circulating in wildlife and cattle of the greater Kafue ecosystem, Zambia. Parasites Vectors 2020, 13, 599. [CrossRef]

42. Amer, S.; Ryu, O.; Tada, C.; Fukuda, Y.; Inoue, N.; Nakai, Y. Molecular identification and phylogenetic analysis of Trypanosoma evansi from dromedary camels (Camelus dromedarius) in Egypt, a pilot study. Acta Trop. 2011, 117, 39-46. [CrossRef] [PubMed]

43. Elhaig, M.M.; Sallam, N.H. Molecular survey and characterization of Trypanosoma evansi in naturally infected camels with suspicion of a Trypanozoon infection in horses by molecular detection in Egypt. Microb. Pathog. 2018, 123, 201-205. [CrossRef]

44. Bastos, A.D.; Mohammed, O.B.; Bennett, N.C.; Petevinos, C.; Alagaili, A.N. Molecular detection of novel Anaplasmataceae closely related to Anaplasma platys and Ehrlichia canis in the dromedary camel (Camelus dromedarius). Vet. Microbiol. 2015, 179, 310-314. [CrossRef] [PubMed]

45. Kidambasi, K.O.; Masiga, D.K.; Villinger, J.; Carrington, M.; Bargul, J.L. Detection of blood pathogens in camels and their associated ectoparasitic camel biting keds, Hippobosca camelina: The potential application of keds in xenodiagnosis of camel haemopathogens. AAS Open Res. 2019, 2, 164. [CrossRef]

46. Ait Lbacha, H.; Zouagui, Z.; Alali, S.; Rhalem, A.; Petit, E.; Ducrotoy, M.J.; Boulouis, H.J.; Maillard, R. “Candidatus anaplasma camelii" in one-humped camels (Camelus dromedarius) in Morocco: A novel and emerging anaplasma species? Infect. Dis. Poverty 2017, 6, 1. [CrossRef]

47. Sharifiyazdi, H.; Jafari, S.; Ghane, M.; Nazifi, S.; Sanati, A. Molecular investigation of Anaplasma and Ehrlichia natural infections in the dromedary camel (Camelus dromedarius) in Iran. Comp. Clin. Pathol. 2017, 26, 99-103. [CrossRef]

48. Koh, F.X.; Panchadcharam, C.; Sitam, F.T.; Tay, S.T. Molecular investigation of Anaplasma spp. in domestic and wildlife animals in Peninsular Malaysia. Vet. Parasitol. Reg. Stud. Rep. 2018, 13, 141-147. [CrossRef]

49. Parvizi, O.; El-Adawy, H.; Roesler, U.; Neubauer, H.; Mertens-Scholz, K. Performance analysis of Anaplasma antibody competitive ELISA using the ROC curve for screening of anaplasmosis in camel populations in Egypt. Pathogens 2020, 9. [CrossRef] [PubMed]

50. Liu, C.; Qi, R.J.; Jiang, J.Z.; Zhang, M.Q.; Wang, J.Y. Development of a blocking primer to inhibit the PCR amplification of the 18S rDNA Sequences of Litopenaeus vannamei and its efficacy in Crassostrea hongkongensis. Front. Microbiol. 2019, 10, 830. [CrossRef] [PubMed]

51. Belda, E.; Coulibaly, B.; Fofana, A.; Beavogui, A.H.; Traore, S.F.; Gohl, D.M.; Vernick, K.D.; Riehle, M.M. Preferential suppression of Anopheles gambiae host sequences allows detection of the mosquito eukaryotic microbiome. Sci. Rep. 2017, 7, 3241. [CrossRef] [PubMed]

52. Reigel, A.M.; Owens, S.M.; Hellberg, M.E. Reducing host DNA contamination in $16 S$ rRNA gene surveys of anthozoan microbiomes using PNA clamps. Coral Reefs 2020, 39, 1817-1827. [CrossRef]

53. Jian, C.; Luukkonen, P.; Yki-Järvinen, H.; Salonen, A.; Korpela, K. Quantitative PCR provides a simple and accessible method for quantitative microbiota profiling. PLoS ONE 2020, 15, e0227285. [CrossRef] [PubMed]

54. Herlemann, D.P.; Labrenz, M.; Jürgens, K.; Bertilsson, S.; Waniek, J.J.; Andersson, A.F. Transitions in bacterial communities along the $2000 \mathrm{~km}$ salinity gradient of the Baltic Sea. ISME J. 2011, 5, 1571-1579. [CrossRef]

55. Matjila, P.T.; Penzhorn, B.L.; Bekker, C.P.; Nijhof, A.M.; Jongejan, F. Confirmation of occurrence of Babesia canis vogeli in domestic dogs in South Africa. Vet. Parasitol. 2004, 122, 119-125. [CrossRef]

56. Njiru, Z.K.; Constantine, C.C.; Guya, S.; Crowther, J.; Kiragu, J.M.; Thompson, R.C.; Davila, A.M. The use of ITS1 rDNA PCR in detecting pathogenic African trypanosomes. Parasitol. Res. 2005, 95, 186-192. [CrossRef]

57. Parola, P.; Roux, V.; Camicas, J.L.; Baradji, I.; Brouqui, P.; Raoult, D. Detection of ehrlichiae in African ticks by polymerase chain reaction. Trans. R. Soc. Trop. Med. Hyg. 2000, 94, 707-708. [CrossRef] 
58. Inokuma, H.; Brouqui, P.; Drancourt, M.; Raoult, D. Citrate synthase gene sequence: A new tool for phylogenetic analysis and identification of Ehrlichia. J. Clin. Microbiol. 2001, 39, 3031-3039. [CrossRef] [PubMed]

59. Sumner, J.W.; Nicholson, W.L.; Massung, R.F. PCR amplification and comparison of nucleotide sequences from the groESL heat shock operon of Ehrlichia species. J. Clin. Microbiol. 1997, 35, 2087-2092. [CrossRef] [PubMed]

60. Liz, J.S.; Anderes, L.; Sumner, J.W.; Massung, R.F.; Gern, L.; Rutti, B.; Brossard, M. PCR detection of granulocytic ehrlichiae in Ixodes ricinus ticks and wild small mammals in western Switzerland. J. Clin. Microbiol. 2000, 38, 1002-1007. [CrossRef] [PubMed]

61. Gofton, A.W.; Doggett, S.; Ratchford, A.; Ryan, U.; Irwin, P. Phylogenetic characterisation of two novel Anaplasmataceae from Australian Ixodes holocyclus ticks: 'Candidatus Neoehrlichia australis' and 'Candidatus Neoehrlichia arcana'. Int. J. Syst. Evol. Microbiol. 2016, 66, 4256-4261. [CrossRef]

62. Urakawa, T.; Verloo, D.; Moens, L.; Buscher, P.; Majiwa, P.A. Trypanosoma evansi: Cloning and expression in Spodoptera frugiperda [correction of fugiperda] insect cells of the diagnostic antigen RoTat1.2. Exp. Parasitol. 2001, 99, 181-189. [CrossRef]

63. Njiru, Z.K.; Constantine, C.C.; Masiga, D.K.; Reid, S.A.; Thompson, R.C.; Gibson, W.C. Characterization of Trypanosoma evansi type B. Infect. Genet. Evol. 2006, 6, 292-300. [CrossRef] [PubMed]

64. Bower, S.M.; Carnegie, R.B.; Goh, B.; Jones, S.R.; Lowe, G.J.; Mak, M.W. Preferential PCR amplification of parasitic protistan small subunit rDNA from metazoan tissues. J. Eukaryot. Microbiol. 2004, 51, 325-332. [CrossRef]

65. Comeau, A.M.; Li, W.K.; Tremblay, J.E.; Carmack, E.C.; Lovejoy, C. Arctic Ocean microbial community structure before and after the 2007 record sea ice minimum. PLoS ONE 2011, 6, e27492. [CrossRef] [PubMed]

66. Bolyen, E.; Rideout, J.R.; Dillon, M.R.; Bokulich, N.A.; Abnet, C.C.; Al-Ghalith, G.A.; Alexander, H.; Alm, E.J.; Arumugam, M.; Asnicar, F.; et al. Reproducible, interactive, scalable and extensible microbiome data science using QIIME 2. Nat. Biotechnol. 2019, 37, 852-857. [CrossRef] [PubMed]

67. Callahan, B.J.; McMurdie, P.J.; Rosen, M.J.; Han, A.W.; Johnson, A.J.; Holmes, S.P. DADA2: High-resolution sample inference from Illumina amplicon data. Nat. Methods 2016, 13, 581-583. [CrossRef]

68. Davis, N.M.; Proctor, D.M.; Holmes, S.P.; Relman, D.A.; Callahan, B.J. Simple statistical identification and removal of contaminant sequences in marker-gene and metagenomics data. Microbiome 2018, 6, 226. [CrossRef]

69. Qiu, Y.; Kaneko, C.; Kajihara, M.; Ngonda, S.; Simulundu, E.; Muleya, W.; Thu, M.J.; Hang'ombe, M.B.; Katakura, K.; Takada, A.; et al. Tick-borne haemoparasites and Anaplasmataceae in domestic dogs in Zambia. Ticks Tick-Borne Dis. 2018, 9, 988-995. [CrossRef]

70. Katoh, K.; Standley, D.M. MAFFT Multiple Sequence Alignment Software Version 7: Improvements in performance and usability. Mol. Biol. Evol. 2013, 30, 772-780. [CrossRef] [PubMed]

71. Kumar, S.; Stecher, G.; Li, M.; Knyaz, C.; Tamura, K. MEGA X: Molecular evolutionary genetics analysis across computing platforms. Mol. Biol. Evol. 2018, 35, 1547-1549. [CrossRef] [PubMed]

72. Guindon, S.; Dufayard, J.F.; Lefort, V.; Anisimova, M.; Hordijk, W.; Gascuel, O. New algorithms and methods to estimate maximum-likelihood phylogenies: Assessing the performance of PhyML 3.0. Syst. Biol. 2010, 59, 307-321. [CrossRef] [PubMed] 